\title{
WHITE HEIFER DISEASE IN Bubalus bubalis - CASE REPORT
}

\author{
KOZICKI, L.E ${ }^{1}$.; SOUZA, R.S. ${ }^{1}$; ARAÚJO, S.L. ${ }^{2}$; SANTOS, I.W. ${ }^{3}$ \\ ${ }^{1}$ Departamento de Medicina Veterinária - UFPR - Ikozicki@agrarias.ufpr.br; \\ ${ }^{2}$ Graduanda de Medicina Veterinária - UFPR; \\ ${ }^{3}$ Departamento de Medicina Veterinária - UFPR (Campus Palotina).
}

During the 40 s there reports were published about anomalies in the heifers genital tract, the so-called White Heifer Desease. Those animals showed either vagina or cervix or corpus uteri parts occluded. The occlusion carried a volumous collection of secretion. The research carried out on this problem confirmed its genetical source. The material of the present case was a buffalo's uterus, collected in a frigorific. The genital tract showed: adherences in both ovaries, a hard horn's assymetry to the right side, being like a 6 weeks uterus gestation. After opening the right horn it was observed a mucous collection of about $100 \mathrm{ml}$ (= mucometra). The right ovary and the oviduct were addered " in totum", in the mesovarium, the ovary measuring 1.3 $\mathrm{cm}$ lenght, $0.6 \mathrm{~cm}$ width and $0.8 \mathrm{~cm}$ height. The endometrium of the right horn was degenerated, very thined and total absent of cotyledon areas. There was a total estenosis, measuring $3.2 \mathrm{~cm}$ lenght, in the corpus uteri and in the beginning of the right horn, measuring $3.2 \mathrm{~cm}$, lenght, remaining however a segment of corpus uteri with lumen. The left horn was normal the cotyledon areas being present. The left ovary measured $1.9 \mathrm{~cm}$ lenght, partially addered in the mesovarium, with the corpus luteum in involution. It was found in the corpus uteri in the direction to the left horn a perforated fibrosis bridle, having an oval orifice $(1.3 \mathrm{~cm}$ diameter) bound to the bifurcatio uteri at the cranial face of the cervix. The left over portion of the reproductive tract was normal. It was concluded that: handled one a White Heifer Disease case, agreeing with the authors that report the finding of estenosis from the posterior genitals segments until the corpus uteri; there is a genetic defect between our buffalo breed, problem that deserve attention.

Key Words: buffalo, white heifer disease, mucometra. 